\title{
Alienation and Loss of Identity in Cameroon Anglophone Drama: The Convergence of History and Politics in Bate Besong's Change Waka and his Man Sawa Boy
}

\author{
Ekpebisong George Otu ${ }^{1}$, Ekangaki Tabe ${ }^{2}$. Bisong Clara B.A, Mbuoben ${ }^{3}$ \\ ${ }^{1}$ PhD Fellow, African Literature, Department of English, Faculty of Arts, University of Buea, Cameroon. \\ Lecturer in Communication and Peace, Pan African Institute for Development, Buea, Cameroon. \\ ${ }^{2}$ PhD Fellow, Political Science, Dept. of Political Science, University of Buea, Cameroon. Lecturer of political \\ economy in the Pan African Institute for Development, West Africa, Cameroon \\ ${ }^{3}$ Lecturer and Head of Department at the Pan African Institute for Development, West Africa, Buea, Cameroon. \\ *Corresponding Author: Ekpebisong George Otu, PhD Fellow, African Literature, Department of \\ English, Faculty of Arts, University of Buea, Cameroon. Lecturer in Communication and Peace, Pan \\ African Institute for Development, Buea, Cameroon.
}

\begin{abstract}
Literature as an expression of society cannot ignore the sociological forces of its society. Such sociological forces include socio-political, economic as well as cultural forces. Anglophone Cameroon literature has been conditioned by such forces, as well as, its history which dates back to 1961 following the re-unification of the two Cameroons to form one nation with different cultural and historical leanings. These has over time, given way for the dominant culture to alienate and become repressive to the less dominant one with the resultant consequence of loss of identity. Exploring the concepts of alienation and identity in the play Change Waka and His man Sawa Boy opens up the internal complexities and contradictions inherent in contemporary Cameroon society today, especially with regards to the selection of its leaders through the electioneering process. Using the lens of the playwright, the paper argues that political alienation in Cameroon is traced to historical roots of the two entities that re-unified in 1961 and that political exclusion in any society is dangerous to its progress, development and national cohesion. Hence, any society that plays pranks with its manner for selecting leaders can easily destroy the collective destiny of a people. The artistic horizon of Be song as a writer bears links with the future which makes the play to swing on the dynamism of time.
\end{abstract}

Keywords: Alienation ${ }^{1}$, identity $^{2}$, politics $^{3}$, History $^{4}$, Bate Besong $^{5}$, Anglophone Cameroon literature ${ }^{6}$

1. Alienation: Alienation is a state of rootlessness, isolation and a growing sense of aloofness that fires up the feelings of not belonging.

2. Identity: identity in this context is viewed as statelessness, loss of identity which denies a people their history, subjecting it to palimpsest, erasure and epistemic violence

3. politics: intrigues and manipulations that tend to invest power in the hands of the hegemonic power holders

4. History: the cultural roots of the two Cameroons that re-united traceable to their colonial origins

5. Bate Besong: Bate Besong is a contemporary Cameroonian Anglophone writer of English expression who has written many plays and collections of poetry. His concern for the minority in the union of the two Cameroons made him to don the mask of a town-crier as a tradition of literature relevant to the experiences and collective predicaments of his people.

6. Anglophone Cameroon literature: the literature written by Cameroonians of English expression whose origin is traced to the North West and South West regions.

\section{INTRODUCTION}

Africa's Post-colonial environment has remained restive, witnessing more turmoil, violence and a slower rate of transformation than most other parts of the world because of its political history of colonialism which delved a crushing blow on the people and their cultures, alienating them from their 
roots. It is this cultural deformity that has given rise to various forms of identity crisis: personal, ethnic, cultural, linguistic, national/collective identities resulting in alienation of all forms. These elements, added to the internal contradictions constitute the springs of Africa's revolutions in their strivings toward grasping control over their own lives. It is against this background that modern African literature was born as a functional art form that mirrors its society realistically.

Colonialism and bad governance can therefore be said to have contributed to the growth and development of literature in Africa in general and in Cameroon in particular, and have also established a link between literature, identity, alienation and nationalist consciousness. Wole Soyinka, Chinua Achebe, Ngugi Wa Thiong'o, Ayi Kwei Armah, Ola Rotimi, Bello Kano and other African writers have used their critical and radical revolutionary writings to bring some dimension of change their respective societies. As a role therefore, literature everywhere has always functioned as the embodiment and interpreter of a people's culture, a conveyor of a people's heritage, as well as, their philosophy, psychology and national character. Indeed, whether cast in the mood of agitation, negotiation or based on historical reconstruction or mythological recreation, literature always has a touch of identity. That quest for distinctiveness makes it an epistemological body for contest and negotiation and as a career of eccentricity (Binebai, 2013) It argues that, the symbiotic relationship between literature and identity is a fundamental linkage to national and racial heritage

Alienation and identity are major themes of human conditions in contemporary society and it is only normal that their pervasiveness should impact contemporary Anglophone Cameroon literature given the historical and socio-cultural forces that have conditioned its making. Alienation is a basic form of rootlessness, which can manifest in various forms: psychologically, physically, spiritually, economically, socially and culturally. The alienated protagonist is very much a recurrent character in much of contemporary Anglophone Cameroon literature. As a general trend therefore. Cameroon literature is better understood by its dichotomy under the rubrics of Anglophone Cameroon literature' and 'Francophone Cameroon literature'. This paper focuses on 'Anglophone Cameroon literature which is the literature written by English people of the North west and South West Regions of Cameroon and whose literature is preoccupied with the collective predicaments of the "Anglophone minority' in Cameroon. The Cameroon Anglophone literature is by and large fairly new and like all things in their youthful stage, it is obsessed with a curiosity for the past and a zeal to create the future. Writers see themselves as the spokesmen of their people, and the Anglophone Cameroonian writers have taken it upon themselves to lead the struggle for loss of identity which emanates from the systematic alienation of the people from public space, to recast as it were a past, and recreate the present, and a future for their people. However, before any feeling of roots can be engendered in any society, it is necessary to understand one's history.

\section{IMPACT OF COLONIALISM IN CAMEROON}

Cameroon, like other independent African nations, was created by the colonizers for their convenience and not for the long term feasibility of the new nation. The country from its formation was made up of desperate and sometimes mutually hostile (ethnic) groups which as a consequence of arrangement by the colonizers now had to live together. In short, colonial Cameroon was an artificial entity, a pseudo-nation. The colonial policy of divide and rule instituted long lasting hatred and divisions amongst the people who by virtue of their common nationality had to co-exist.

Reuniting in 1961 at the Foumban, Cameroonians in general were optimistic that political independence would free them from oppression, suffering and humiliation that characterized their existence under European domination. They were all deceived about that, especially the Anglophones who, as it were, were compelled to suffer a double layer of re-colonization from its partner state. As a consequence, Cameroon today is forging ahead uneasily under a dual layer of time, with the past imposing itself on the present while making meaningful adjustments for the future as a necessary synthesis.

From the onset therefore, the minority Anglophones did not imagine that, soon after their liberation from colonial rule, they would be re-colonized by the majority Francophones and be denied full citizenship in their new country which relegated them to the position of second class citizens. This ascribed second class status has created internal rifts and tensions between Francophone and Anglophone Cameroonians which has crystallized into what has come to be known as the 
"Anglophone problem". Unfortunately, this has found expression in issues of alienation resulting from the loss of identity and seriously interrogated the notion of the Cameroonian nation and its banal slogan of a 'one and indivisible nation'. Hence, the issues of alienation and identity have become dominant themes in Anglophone Cameroon literature. These are the central themes which have preoccupied Bate Besong, as an Anglophone Cameroonian writer..

The union of the two nations in to one was supposed to create a new unique identity for both parties of the new nation while shading off their identities held before coming in to the union. Unfortunately, the persistent and dominant Francophone leadership either consciously or unconsciously repeated some of the errors of the colonizers. The successive regimes have also failed to consider and address some of the internal rifts and tensions created by colonialism as well as respect and implement the articles of the constitution that uphold and safeguard what British Southern Cameroon brought along to the union in 1961. In order words, the Francophone dominated governments did not and still do not engage in inclusive policies which has created the desire of Anglophones to continue to look backward in glorification of their historical past (roots) giving room for the gradual buildup of nationalist consciousness. All these and more have led to what has become known as the "Anglophone problem' which has to do with the marginalization, assimilation and undemocratic practices. This has given room to the non-respect and manipulation of the country's constitution in all attempts to alienate Anglophones politically and keep power with the hegemonic power holder (Francophone). Put differently, it can be said that colonialism and bad governance have contributed enormously to the 'Anglophone problem' in Cameroon.

In the play Change Waka and Man Sawa Boy, Besong weaves together history and politics, portraying how cultural differences emanating from a people's historical origin influences political behavior with a sinister plan to confiscate and keep power permanently in the hands of the hegemonic group. This overlap of history and politics is seen in the fact that, Besong approaches the society's social evolution and the gargantuan 'Anglophone problem' from the vantage point of political alienation and the problem of identity. To put this more precisely, political alienation is portrayed through the vehicle of corrupt electoral practices as a well contrived strategy to invest power in the hands of Franco phones permanently and in same manner alienate Anglophones from holding power.

The playwright uses the symbolism of 'the City' to segment Anglophones as Southern Cameroonians of the 'graffis' and 'sawas', whom the government has infiltrate over the years to implant suspicious and unhealthy competition, so as to continue unabated to rule them as a set of 'subalterns' who have no agency for action and unduly exploiting them in the process. As Besong vacillates between politics and history in circles, each as a means of critiquing the other, means that his work has a lot to offer contemporary critical scholarship, especially from the Cameroonian context where historical origin determines who holds power and who does not. Ajayi (1990:41) underscores the importance of history in nation building when asserts that:

The nation suffers which has no sense of history. Its values remain superficial and ephemeral unless imbibe with a deep sense of continuity and perception of success and achievement that transcends acquisition of temporal power or transient wealth. Such nation, cannot achieve a sense of purpose or direction or stability and without them the future is bleak.

The playwright notes that, from their roots, the two people divided into Sawas and ' $\mathrm{La}$ 'a Kham designation are clearly incompatible with citizens of 'Epeng Ebho', as Doh (2004) explains thus:

From the names 'Sawa' and 'La' 'a Kham', it becomes obvious now that the Anglophone predicament is being made more complex by introducing the South West Region into the larger Sawa commune which includes the Doualas, while attaching together the Graffi of the North West Region and those in the Francophone West and Littoral Cameroon together under, the 'La'a kham designation. The situation has just become more complicated for Anglophones who have now become separated along cultural instead of historical lines. The implications are more complex than meet the eye (Doh, 2004:174-175).

Besong in this play, ferries us through a land where election rigging is the principal machinery use for political exclusion of a vast majority from deciding leadership over them. Ngutarh, Arahmbuoh, Mfornyor Mfornyor the 'sous prefets' at Epeng Ebho's Ministry of election are the conduits through 
which elections are manipulated. We can seepolitical alienation in the play as a yardstick for explaining political behavior. Aspects of alienation like political meaninglessness, powerlessness or mistrust are important intervening variables that emanate from a citizens social background leading to his political behavior. Political meaninglessness therefore, occurs when there is little or no predictability with regards to political events. In line with this condition of political alienation, the individual is deprived of making any meaningful political choices and hence cannot contribute in making any social change in his society.

Mister Change waka, the protagonist in the play is entrusted with the role of a messiah who can drive in sanity to change the decayed filthy, smelling society that tends to alienate and exclude the voices of others through elections rigging. His mission can be seen as working hard to put a stop to political alienation as we hear him in the following words thus: 'Rigging was certified dead .Today, it triumphantly carries its death certificate in its breast pocket... if you agree, my friend, we will find a way of getting to Athens. But you must belief me, you have sent out a road show and you will be rigged out if you stay' (22)

The social universe of the writer is a rotten society and political normlessness is the order of the day. Political normlessness is traced to Emile Durkheim's theory of anomie. Anomie is experienced when the individual believes that the rules that govern political relations are not being respected and that corruption and self-serving political gymnastics have taken over fair play. Power in any democratic polity like in Cameroon which is the playwright's setting, is obtain through the ballot box. Invariably therefore, the politically alienated person equally gravitates to a position of powerlessness and becomes fully alienated from his society.

In the society of change waka, politics and power have a direct influence on the economic environment which is the reason why the conscience of those identified as election riggers in the play can easily be bought. All these are done to disproportionately increase the grandeur and power of the king of corruption, Gknockor. The play is replete with imageries that inform the reader about the unhealthy state of that society. Mister change Waka, the change agent in the play confirms this in many instances. Consider the effectiveness of conveying the image of a corrupt nation from the standpoint of a parish that rot has set in.

... we in this parish have proven on several occasions that during this hard time that rot has set in ... Unless we know how to weep with a sorrow and compassion which resembles when mister change Waka weeps at seeing unfairness, disloyalty, and rigging around him, we will never be able to laugh as he does in Abho Amort, now. It is better to recognize that one is darkness than to pretend that one cannot see the light ... (17). Elsewhere in the play, change Waka, talks of decaying teeth that smells making us feel ashamed when laughing in public: We use the front teeth for tearing meat and NyamaNgoro and then send it to the jaws where there are special teeth for grinding. Decaying teeth smell and we feel ashamed when we laugh in public. (22). All these eschatological imageries used in the play are intended to convey to us the extent to which the society of the playwright has degenerated.

In addition, Besong uses the powerful tool of songs as a communicative medium to put across stronger messages which are sometimes even stronger and more evocative than conversations rendered by the characters. It is an extraction from Greek theatre. Anyone who has read Greek tragedy will understand what an important and elevated place the chorus had in the performance as a whole, no matter how obliquely related their songs may be to the plot of the play. Besong's authorial presence in the play is rendered through songs and is typical of him to use women to play revolutionary roles. In the play The Banquet: A Historical Drama one his earlier plays, he used the 'Takemnbeng women collective' to electrify the play with mind throbbing revolutionary ideas emblazoned in riddles.

Being a revolutionary writer with a gender sensitive mind, in the play Change waka, he employed same theatrical techniques of dirges and songs rendered by women bearing out the inner mind of Besong on issues of alienation and identity. The women sing about sycophants who play a very dirty rule in destroying the society by accepting the unacceptable, especially in electioneering matters. A sycophant is an alienated person who suffers exclusion and beliefs that one way to get himself/her into the power orbit is by renouncing himself of what he is known and taken to be. But more often, 
this is done at the peril of the sycophant who can be seen as destroying his power base as a result of ignorance.

The use of the word sycophant is fundamentally relevant given the context of the play which form the backdrop from which interpretation can be generated. Anglophones in the union of the two Cameroons suffer a lot of alienation and marginalization from the majority Francophone who, over the years have developed a mindset of seeing Anglophones as their inferior counterparts. This unfortunate syndrome has led to playing the self-seducing game of the ostrich among Anglophones as a strategy for survival. This is the nodal point from which sycophancy amongst Anglophones blossomed and is still on prowl.

Election rigging as echoed by the playwright forms the crevice through which the dominating Francophone- led- administration constantly ploughs itself back to power and uses it to put the people of the 'Sawa' and the 'Graffi' at loggerheads. It is these people of the 'Sawa South' and the 'La'akham- graffi West' that the women in their dirge call sycophants. This division tended to build a wall between the two and breed misunderstanding while the Francophone continue to reap off the benefits like Achebe puts it in Arrow of God, that, "when two brothers fight for something, a stranger always reaps the harvest'.

Mister Change waka therefore, warns those engineering the divide and rule amongst the people of 'This City' in very stern words, 'we pray for those pushing mankind into a world of Sawa and La'akham thermonuclear war. Hatemongers in front, hatemonger's behind". The 'prefectures' splattered all over 'The City' are sign-post of alienation. Through these 'prefectures' the people remain permanently marginalized and alienated even from their God given natural resources. The prefecture cannot only be seen in line with election rigging. They are the conduit pipes through which the people remain alienated, from the language point, down to resources. Mr Change Waka, the protagonist of the play describes these 'prefectures' as "loot-dispensers... oil bank accounts (23).

The play Change Waka and His Man Sawa Boy is replete with the Marxist ideology that views society from the change dimension which comes as a result of class struggle. The class struggle in the universe of the play Change waka, is between those vested with power like Gknockor, the imperial Excellency of Epeng Ebho, Mfawbahep Gknockor, Ayukangou, Ngutarh, Arahambuoh who are the 'sous prefets'(s) at Epeng Ebho's Ministry of elections, Sessekou Daniel Atemengeng and the Kangaroo judge of state at the Ministry of Elections, all have asymmetrical power relationship compared to others like Nwa Agbor Bessem, Eyere, Ewube, Akonjweu nobody Amos etc. This inbuilt class structure between the have -muchand the have-nots in the society of the playis the driving force of Besong's, stand as a representatives voice of the agonized and suffering Anglophone masses who are trapped in poverty, victimization, oppression, and the systematic exploitations of their resources.

Mister change Waka therefore, stands as a balance on the scale of social stratification and inequalities. He represents a new order, a new society and future as he speaks to the audience in a passing phrase:

"In Epeng Ebho the law has grown an ugly gap tooth. They may say: Now, the way is open for us to go up the ladder in the criminal world. But, he who is holding somebody on the ground is holding himself too. It amount to cutting your nose, your lips and blinding your eyes to spite your face. So, you may do great thing with procedural flaws and pendulums, but if you go down that road, you will suffocate like the bad loser of divided loyalties (25).

The plays' echo on alienation is clear and total as the overlords of Gknockor and his gang and collaborators in the persons of 'sous prefets' amass the wealth of the people to satisfy themselves and their Western political progenitors, earlier described by Mister change waka as loot dispensers... whom oil money finds its way into foreign private bank accounts.. (23).

In his book, "The clash of Civilizations and the Remaking of world order" (1996), Samuel P. Huntington made a very declarative statement when he noted that clashes between civilizations will constitute the greatest threat to world peace in the post-cold war years. In the contemporary 'global village' today, people and states have moved from defining themselves on the basis of ideology or economic to cultural. World politics therefore, is being reconfigured along cultural lines which have spewed up new patterns of conflicts, especially in Africa where arbitrary boundaries and mergers 
forced on people following colonial expansion is akin to a time bomb, as has been witnessed in Bosnia, Chechnya, Central Asia, Kashmir the middle East, Tibet, Sri Lanka and many other places. In Cameroon, dating back from 1961, the union between French Cameroon and English Cameroon (Southern Cameroon) have confirmed Huntington's declarative statement given that, increasingly the duality of the union is in constant opposition because of cultural roots traced to different colonial legacies acquired from the French and British.

. Forty one years of separate existence under the different colonial tutelage nurtured an exogenous imprint of Western intrusion into the respective social consciousness of the two Cameroons. By dint of this understanding, the Southern Cameroons which is made up of English speaking people trace their identity to history, geography and language which equally holds same for French speaking Cameroon. It is this backdrop of history that Besong projects through artistic de-familiarization in the play Change Waka and His Man Sawa Boy.

The society of the play Change waka is controlled by the elite and national bourgeoisie who have embraced the ideology of capitalist neo-colonialism which, like its bed-fellow colonialism, exploits the marginalized women whose origin is traced to the Anglophone fold. Their identity is revealed to the reader when in their dirge, after electoral victory has been proclaimed by Atemengeng and was accompanied by unreasonable fanfare in churches, homes, stadium, kiosk and drinking in all houses throughout Epeng Ebho, the women took the centre stage singing thus:

\section{..It is because sycophants}

Have nothing to contribute

To making

Of elections

All they do

Is distract attention

But we of this city

are not doomed

To be ruled

By the might

Of the French

Gun ... (28)

Identity in the play can be understood from the standpoint of the playwright's 'imagined communities' of Epeng Ebho and 'This City'. It is implied from the women's dirge that 'This City', is a society that gives full value to its people but is still an 'imagined community' hence, the struggle of the masses for their lost identity remains on-going as echoed suit, 'But we of 'This City' are not doomed to be ruled by the might of the French gun'. The playwright here employs the symbolism of 'This City' to drive home the identity issue which has led to political alienation. Elections are rigged to continuously perpetrate Francophone dominance over Anglophones which has led to an asymmetrical power relationship in the 'Francophone-Anglophone' national equation.

In playing the role of the native intellectual, the playwright proves with enormity, that the truths of a nation are in the first place its realities. In the same vein, Fanon (1963) in "On national culture" argues that, since African history, culture and identity have been displaced, disfigured, or destroyed by colonialism, it is the task of the native historians, intellectuals and artists to illustrate "the truths of the nation" (1963:225). The implied understanding here is that, the artist must interrogate the conflict which colonialism has imposed on the people and consequently "write back" to the colonizers not only for the sake of the present moment but also to reclaim the lost past in order to forge a national future and liberate themselves from the occupying power.

Mister Change Waka in the play recognizes that, darkness has invaded 'This City' because of the occupying power and weeps with sorrow and compassion stating that 'it is better to recognize that one 
is in darkness than to pretend that one can see the light'. Supporting what change waka says, Akonjwen Nobody Amos, Change Waka's personal aide equally explains that; 'all of us need spiritual food to keep our faith alive and strong. (to the audience) there was no one who came to deliver a message that was good for the people of 'This City'. Who was not opposed by the Ayukangous, the mfornyors mfornyors and sesekou Daniel Atemengengs ... saliva freely flows from their mouths and they fail at toilet training, A frog does not die in the mud. Avoid being misled... (18).

As a malleable construct, nationhood is historically contingent. Any attempt to understand Besong's construction of 'This City', nationhood and identity in the play requires the historical contextualization of 'This City' in its struggle to transform itself from a la Republic du Cameroon appendage state in search of its identity and self-determination. Besong therefore, makes use of both the cultural and the political forces to construct nationhood and identity in the play. Change waka tells the audience, with a puzzled smile on his face, 'уou are the unbaptized minister of the Iglesia Nueva Apostolica... by Efhiim ... Tarry in peace. Tarry in war (with a half-smile) I fear you have a difficult task. But I wish you success for, an electoral lie is the truth intrinsically; it holds a lawful place in the state of our union ... (30).

The playwright beliefs that the cultural intermingling between the dominating Francophones and the dominated Anglophones to form an unstable or ambivalent identity and cultural space or what Homid Bhabha calls 'Third space of enunciation', has not worked. Through political gerrymandering, the relationship between the two people constantly shapes and reshapes what it means to be the colonizer or the colonized; and each exchange is a negotiation of identity giving room for hybridity. Hybridity attempts to deny pure identity. This ambivalent space is obviously played out in characters like Mfawbahep Gknockor, Ayukangou, Ngutarh, Mforyor Mforyor and sessekou Atemnengeng. These are agents who fluctuate between the culture of the oppressor and the oppressed. Hence, Mister Change Waka says: 'only a fool believes that he can put back the clock? (30), insisting that truth have a metaphysical propensity to lay bare what has been concealed for years... (32). Bhabha (1994:51) again explains that identity is never an apriori, never a finished product. It is only ever the problematic process of access to an image of totality. Hence, the search for identity in the play is a search for completeness. It is the grasping of an illusory image of totality fostered through an imaginary unity of self.

Mister Change Waka illustrates this stand point when he spoke of settler electors as strangers whom according to him betrays the interest and aspiration of the people because of loyalty that is rooted elsewhere.

The conflict of the play is well anchored on the state of disharmony or clash between incompatible persons holding different ideas and or interest. This is clearly manifested through Mister Change Waka, whose perceived incompatibility with loot dispensers helps to heighten the conflict. Mister Change waka is therefore pitted against the 'sous prefets' and all other agents of electoral fraud who have rendered the society irremediably corrupt like 'decaying teeth' in the mouth of an old man'. Besong points to materialism as another deep seated root of the conflict where a great number of characters in the play exhibit excessive greed for money and material things. This unfortunate and unbridled appetite for wealth breeds a tendency for corruption in that society and like Change Waka explains "oil money finds its way into foreign private bank accounts, (23) Greed makes sessekou Atemengeng such a ruthless judge of state at the ministry of elections, whose inability to keep law and order nor execute them is very apparent because of his materialistic inclinations.

Mister Change Waka is at the vanguard of the struggle to liberate the society from dictatorship whose import is mightily felt through rampant election rigging. Thus Besong amplifies the conflict by moving it through material inclination to cultural identity manifested through two societies of Epeng Ebho and 'This City'. Allusions about this are repeated in the play like in 'in Epeng Ebho the law has grown an ugly gap tooth'... (25). Again, after the proclamation of victory by Atemengeng, portrait of the infallible sessekou are splattered virtually throughout Epeng Ebho. This is a clear portrayal of a society in complete disorder as compared to 'This city'.

There is clear demonstration of bad governance, Gknockor and his compradors govern their society outrageously without logic or reasoning. There is the absence of the defense of the rule of law, rather, what obtains is uncoordinated orders of what is to be done, passed through cronies (sous prefets). 
These set of people are seen as pathological liars, cheats and fraudsters whom any right thinking leader should distance himself from. They are the vectors of corruption in Epeng Ebho which gnaws at the society gradually, leading to suffering amongst the citizens. The power game of the play is cleverly achieved through election adultery as Besong calls it 'a cancerous ailment that has slowly but surely destroyed Epeng Ebho'. All the cronies of the society of Epeng Ebho have weak minds towards corrupt. The 'sous prefets' are very inconsiderate human beings and will do anything to earn fortunes from anywhere possible.

Besong always has an over bearing presence in his works. In this play one sees him speaking through Mister Change waka, as a change agent of the society of the play. Edward said, illustrates this in his important work, Orientalism, in suggesting the fallibility of the 'truth'. His view holds that, the author, whether fiction or historical narrative, is always present in the text.Another identity marker used by the playwright to reinforce and clearly distinguish the people of 'This city' is the use of the term 'settlers'. Settlers are people of 'Epeng Ebho' who have settled in the imagined community (This City). The playwright is of the opinion that, the problems faced by 'This city' are predominantly a product of the political climate of 'Epeng Ebho' extended into 'this city'. From a social action theory perspective,the society in the play has developed from the interaction of two broad cultural streams (the Francophone and the Anglophones).

\section{CONCLUSION}

The minority Anglophones in the union with the majority Francophone in Cameroon are the victims of alienation in their society. They struggle to negotiate vital space for survival. To do this, they have to discard their identity to play buffoon, if necessary. This has been demonstrated in Besong's change waka where Anglophones are sycophants and election riggers whose second class status in their social relations with Francophones has blindfolded them to the extent that they can act ultra-vice even to destroy their own 'power base' as a survival strategy. The story of the alienated Anglophones cannot be concluded without the struggle to liberate themselves from alienation by reasserting their identity and Bate Besong as a playwright remains positive on the outcome of that revolution.

\section{REFERENCE}

[1] Bate, Besong. (2001) Change Waka and His Man Sawa Boy. Yaounde (Cameroon): Editions Cle.

[2] Shadrach A. Ambanasom (2012) perspectives on written Cameroon literature in English, Bamenda: Agwecam printers.

[3] Ajayi J. F. A (1990) History and the nation and other addresses, Ibadan Spectrum books.

[4] Benedict Binebia. (2013) "Literature and identity: Africaand the Diasporic Experience". The Dawn Journal, Vol.2, No. 1, 2013.

[5] Carol M. Sicherman (1989). "Ngugi wa thiogo and the writing of Kenyan History" Research in African Literature, Vol.20, No 3, Indiana University press.

[6] Dick Sztanyo, M.A (1996). 'Faith and Reason', Montgomery: Apologetics press.

[7] Fatina, Balci. (1987) 'The Marxist concept of Alienation and Exploitation in 'Of mice and Men', University of Gothenburg.

[8] Forje J. W (2009) Challenges of administrative, political and Developmental renewal in Africa, New York. Nova science publishers Inc.

[9] Iwuchukwu, Onyeka. (2013) 'The Constructive Reformative and Revolutionary image of the African Woman in Ngugi Wa- Thiong'o's. The Trail of Dedan Kimathi and Femi Osofisan's Morountodun'. International journal of language, literature and Gender studies, vol.2 (1).

[10] Jeffery A. Simpson et al. (2015) power and social influence in relationship. American psychological Association.

[11] Lisa Veneklasen and Valerie Miller. (2002) "Dynamics of power, inclusive and Exclusive". Oklahoma City: World neighbours.

[12] Ludwig Von Mises (1963). "Human Action: A treatise on Economics" $4^{\text {th }}$ edition University of Yale press.

[13] Mickhail Lyubansky and Elaine Shpungin. (2004) "Challenging power Dynamics and Restorative Justice", University of Illinois.

[14] Murfin, Ross and Supryia M. Ray. (2003) The Bedford Glossary of critical and Literary Terms. $2^{\text {nd }}$ ed. Bedford/St Martin'. 
Alienation and Loss of Identity in Cameroon Anglophone Drama: The Convergence of History and Politics in Bate Besong's Change Waka and his Man Sawa Boy

[15] Nicholas Vrousalis. (2011) “Exploitation of man by man”, Ku Leuven, Belgium.

[16] Nalova Lyonga, Eckhard Breitinger, Bole Butake (eds) (1993) Anglophone Cameroon Literature, Germany, Bayreuth University.

[17] Robson, Stephen. (1987) Ngugi Wa-Thiong'o's Fight against Colonialism and neo-colonialism. An exploration of the theme of Betrayal. Master thesis. Simon Fraser University.

[18] Satyananda J.G. and Eugenia O. Todorova (2002). "Racism and capitalist Accumulation: An over determined Nexus," journal of critical Sociology.

Citation: Ekpebisong George Otu, Ekangaki Tabe. Bisong Clara B.A, Mbuoben. "Alienation and Loss of Identity in Cameroon Anglophone Drama: The Convergence of History and Politics in Bate Besong's Change Waka and his Man Sawa Boy". International Journal of History and Cultural Studies (IJHCS). vol 4, no. 1, 2018, pp. 81-89. doi:DOI: http://dx.doi.org/ 10.20431/2454-7654.0401006.

Copyright: (C) 2018 Authors. This is an open-access article distributed under the terms of the Creative Commons Attribution License, which permits unrestricted use, distribution, and reproduction in any medium, provided the original author and source are credited. 